\title{
Scholar and Spokesman: Benoy Sarkar on the West, Religion, Nationalism and Internationalism*
}

SUMMARY: Benoy Kumar Sarkar was both a serious scholar of history and society and a spokesman who wanted to promote ideas of equality between East and West and highlight the secular achievements of the Hindus. He has been hailed as a pioneer of Neo-Indology, a premature postcolonial sociologist, a conservative nationalist and an anti-colonial internationalist. Elements of several ideologies can be found in his writings. This article assesses his critique of orientalist constructions of East and West, the features of Hinduism and Buddhism and their influence overseas, the peculiarities of nationalism and Hindu-Muslim relations in India and the conservative, authoritarian and cosmopolitan elements in his writings on nationalism and internationalaffairs.

KEYWORDS: caste, race, nationalism, East and West, arthik unnati, Hinduism, vishwashakti

Benoy Kumar Sarkar (1887-1949), a leading intellectual of the first half of the $20^{\text {th }}$ century, was a professor at Calcutta University. Travelling in Europe, America and East Asia for more than a decade he befriended

All Sanskrit and Indian vernacular terms, titles and names that appear in this paper use the English spelling. 
influential academics and was often welcomed as the voice of a new Asia and the "intellectual life of the Orient" (Sarkar 1938a: vi). This article will explore some of his thoughts on the essential similarities in responses of human beings to similar stimuli in both East and West (Mukherjee 1950: 134-138). ${ }^{1}$ It will also explore Sarkar's writings on religion and religious identities and his understanding of nationalism and internationalism. Sarkar, a Bengali intellectual, was both a scholar of and a spokesman for Hinduism and Indian nationalism. Despite his fascination with fascism Sarkar believed in democracy. Despite his sympathies with revolutionary nationalism and anticolonialism Sarkar never abandoned notions of internationalism and cosmopolitanism.

The victory of Japan in the war of 1905 against Russia had a deep impact on Sarkar. It marked the first victory of an Asian power against a European one. The revolutionary nationalism associated with the Swadeshi movement in Bengal also affected him significantly. This attachment to revolutionary nationalism remained with him throughout his life. Despite his generally positive assessment of Gandhi, he identified with the more militant anti-imperialism of Subhas Bose in the 1940s. Manu Goswami hails him as a scholar who anticipated Edward Said's critique of Orientalism by about sixty years eminently worthy of being placed in a pantheon of anti-colonial internationalists of the inter-war period. ${ }^{2}$ Benjamin Zachariah places him in the company of those who are on the fuzzy edges of fascism because of his admiration for Nazi Germany (Zachariah 2015b). Although Satadru Sen regards

1 The Indians are no less practical and positivist than the Eur-Americans nor are they less moral and spiritual than the Indians. Mukherjee asserts, "this dictum of fundamental equality between the East and the West is the soul of the science of Neo-Indology" (Mukherjee 1950: 136). For a recent assessment of spiritualism in East and West, see Veer 2001.

2 Writes Goswami, "While terms such as «Occidental reason» prefigure the language of current postcolonial studies, Sarkar's project was animated by a commitment to effect commensurability rather than claim radical alterity" (Goswami 2013: 161). 
Sarkar as a right-wing figure he rejects the charge of fascism. He also finds recurring instances of ambivalence, ambiguity and delusions in Sarkar's oeuvre (Sen 2015). ${ }^{3}$

These significantly different assessments emerge partly because of the texts the scholars choose to highlight as well as the interpretation of those texts. It is also partly because Sarkar's academic texts are sometimes inconsistent with his more popular and journalistic writings. It is also because his views evolved over time in response to significant events like the Great Depression. Based on his early writings Clement Six has adjudged Sarkar as a global thinker and a "conservative Bengali nationalist" (Six 2018: 434). This article will examine Sarkar's understanding of East-West relations, Hinduism, nationalism and internationalism in order to foreground the specific arguments that he advanced as well as the ambiguities and contradictions in his thought.

\section{Equality, similarity and difference between East and West}

If there is a core idea that informs Sarkar's understanding of history it is the equality and similarity between the East and the West (Sarkar 1938a: xiii-xiv). ${ }^{4}$ For Sarkar the gap between the West and the East begins in the late $18^{\text {th }}$ century and becomes significant only with the age of steam in the early $19^{\text {th }}$ century. He produced a typology or schema which compared levels of development in India and the West (Sarkar 1942a). ${ }^{5}$ He argued that the only "Dark Age" of India was in the $19^{\text {th }}$ century when the West gained decisive supremacy based on technological and economic development (Sarkar 1922: 262). This anticipates

3 Sen argues that "Sarkar was not so much an outlier as an alternative within Indian nationalism" (S. Sen 2015: 31).

${ }_{4}$ In 1922 Sarkar declared "that reform in social science will be possible only when this equality or fundamental similarity between the East and the West is accepted as the first postulate in all scientific investigations" (ibid.: xiii-xiv).

He estimated that India in 1853 was at the level of England of 1785 and France and Germany of 1830 (ibid.: 5). 
the debate on the great divergence between Europe and the East sparked by Kenneth Pomeranz (Pomeranz 2000, Parthasarathy 2011). He briefly refers to the role of Bacon and Newton in preparing the ground for significant progress in the $19^{\text {th }}$ century but the real gap only emerged in the $19^{\text {th }}$ century. Sarkar believed that the Industrial Revolution and the French Revolution had unleashed forces that were playing a vital role in the life of India. Therefore, he recommended "a manly fraternising with other nations" based on "humanistic give and take" (Sarkar 1938a: 9). Indians had to learn how to use 'varied world-forces' to strengthen themselves in multiple ways (ibid.).

Although Sarkar repeatedly asserted the vitality of Hindu energism in various works he went so far as to state that "by the worldstandard Young India's greatest men, institutions and movements continue still to be third-rate or fourth-rate in quality, quantity and variety. Let us be bold enough to face the objective realities without camouflage" (ibid.: 22). In a lecture that Sarkar delivered in January 1926 in Calcutta he emphasised the need for an intellectual and spiritual reconstruction of India. Those who believed that India was 'the guru of mankind' needed to face the fact that the men and women of Eur-America were "morally, intellectually, aye, spiritually far above the men and women of Asia" (ibid.: 63). Lloyd Rudolph has traced the influence of the 'other west' in Gandhi's critique of industrialization and modernity in Postmodern Gandhi and Other Essays (Rudolph and Rudolph 2006). In the case of Sarkar there is a greater willingness to incorporate ideas about political and economic development based on the whole range of western scholarship about democracy, capitalism and socialism.

Sarkar's claims about the similarities between the East and the West are not based only on his broad assessment of the history of the two continents. Taking a longer view of history he argues that the Hindus and Asians were as good at war and conquest as the Europeans. It is also founded on an understanding of human nature. On the basis of comparative anthropology and psychology as well as his own judgement Sarkar claimed: 
Two master-passions have made man here and there and everywhere - both in the East and the West. These are, first, love, and second, war, or first, war, and second, love. The literature of the Hindus from the age of the Maurya emperors (third and fourth centuries B. C.) to the age of the Gupta Napoleons (fourth and fifth centuries A. C.) is the literature of war and love. (Sarkar 1922: 266)

His recognition of the passion for war and his understanding of the social and economic consequences of wars led him to propound a militaristic interpretation of history. This was by and large a counter to the Marxist and progressive emphasis on an economic interpretation of history. The fascination with wars he shared with many Bengalis of his time but it was more than that. He was also claiming parity with the West in terms of the martial qualities of Asians regardless of race or religion. The construction of the argument is in terms of the relationship between two large continents. Europe expanded its influence steadily between the battle of Plassey in 1757 and the Asian victory in 1905. This European expansion was itself a response to the fall of Constantinople in 1453 to an Asian power - the Ottoman Turks. Writing in 1918 he asked, "does this series of events during 150 years entitle the sociologist to propound the jingo cult of difference between the East and the West? This is the first question in the Critical Philosophy of Young Asia" (Sarkar 1918a: 524).

Sarkar claimed parity with the west both in terms of good and bad attributes. As he acknowledged, “the Hindu Louis's, Fredericks and Peters were as good or as bad 'enlightened despots' as were those of Europe" (Sarkar 1922: 251). He applies the same standard to judge rulers in both East and West. It is not appropriate to pass judgement on Sarkar's ressentiment nationalism without exploring simultaneously the impact of the repression and racism of colonial rule on subjects of Empire like him. Sarkar's anti-imperialism does not cloud his judgement. He goes so far as to state that poets like Virgil and Kalidasa, or great nationalists of their times, "paralleled each other in jingoism, in chauvinistic imagination and glorification of their own races" 
(Sarkar 1938a: 100). This assessment does not accept the cultural superiority of either East or West. Open to new influences from the West in literature and the arts he is not preoccupied with cultural incommensurability and authenticity. Speaking of love-the other master passion he has identified-Sarkar writes, "there is no Oriental love, and there is no Occidental love" (Sarkar 1916a: 52). Critiquing the spiritual interpretation of the songs of Vidyapati by Ananda Coomaraswamy he commends Vidyapati's secular celebration of carnal or 'absolute' love as "an elemental motive power." He rejects interpretations of Chitra, Radha and Urvashi in the works of Tagore, Vidyapati and Kalidas "in accordance with the conventional ideas of Hindu decorum or Indian domestic morality" (Sarkar 1916a: 51).

As we have seen Sarkar acknowledged that the West had forged ahead because of the Industrial Revolution but this Europe was not conceived as a monolithic entity. Sarkar's West had developed countries as well as regions of "lags" (Sarkar 1942a: 55) and some Asian countries were on par with the regions in Europe that lagged behind. On many occasions Sarkar produced tables of what he called "equations of comparative industrialism." He claimed that the socio-economic equations or parities between India and Balkan Eastern Europe "are significant as theoretical contributions to modern philosophy and have deep practical values as well in regard to economic statesmanship and societal planning with special reference to semi-developed regions" (ibid.: 53) These equations cannot be easily stigmatized and dismissed as a "stagist view' of history. Besides, as a non-Marxist, Sarkar does not see any 'logic of capital' and so its relationship with 'difference' is not a problem for him as it is for Dipesh Chakrabarty (Chakrabarty 2000: 9). ${ }^{6}$ In Sarkar's reckoning, for all practical purposes, 'Europe' was not so

6 Chakrabarty has argued that "a third-world historian is condemned to knowing "Europe" as the original home of the "modern," whereas the "European" historian does not share a comparable predicament with regard to the pasts of the majority of humankind" (ibid.: 42). 
much the "original home of the modern" as it was a pioneer of arthik unnati or economic growth. ${ }^{7}$ He opined,

Arthik Unnati [i.e., economic progress] is not the function of any special philosophy, social, political or international. The science or art of economic progress possesses a swaraj (independence) of its own. It cannot be subordinated to any other discipline. Like Geopolitik it is orientated to the most diverse vishva-shakti (world-forces). (Sarkar 1943a: 179)

As Sarkar believed in the essential similarity between East and West there was no need to provincialize Europe. To claim parity was sufficient. Sarkar believed that India, like Poland, was a "region of 'lags"” (Sarkar 1942a: 55). He concluded that Italy was a bridge between the Balkan countries and the developed or adult countries of western Europe. The young industries of Italy could be regarded as "the connecting link and transition between Young Asia and the grown-up Eur-America” (Sarkar 1926: 263). As he had stated in The Politics of Boundaries, Italian experiments in economic development and nation making represented, "the cultural bridges over which semi primitive, semi developed peoples will have to pass in their strivings after fuller and richer self-realization" (Sarkar 1938b: 203) ${ }^{8}$

Italy — a second class nation — was nearly as far behind the pioneers of industrialization as India. The advanced countries were undergoing a second industrial revolution while countries like India, China and Russia were experiencing the first industrial revolution. He believed that the standard of living in the countries of the second industrial revolution "can be raised only to the extent of a simultaneous development of purchasing power by industrialization in the regions of the first industrial revolution." In the context of the Great Depression

For Sarkar Europe is not homogenous or monolithic and the ideals of freedom were universal, not exclusively European. Modernity was not an all-encompassing category of analysis for Sarkar as much as arthik unnati was. Japan had become inferior to the West "only because it had not independently produced the steam engine" (Sarkar 1922: 19) not lack of some capacious concept of modernity.

Also see Sarkar 1937a: 484. 
of 1929-1932 he argued that "the two industrial revolutions of the present world economic depression constitute one socio-economic complex" (Sarkar 1942a: 27). The standard of living of the working classes in the developed countries - the adults - would rise if there was a 'simultaneous improvement' in the purchasing power of peasants in the backward regions — the youngsters (Sarkar 1932: 261-301, 292). ${ }^{9}$

Nationalist intellectuals highlighted the role of democratic institutions and ideas in ancient India-the Vedic Sabha, the Janapadas and the panchayats. Sarkar himself translated the Sukraniti of the sage Shukracharya (Sarkar 1914b, 1918d). The reliability of the Sukraniti has been questioned because it had incorporated translations of several laws of the colonial government (Gopal 1962). Sarkar's more substantial claim was that it was only after the late $18^{\text {th }}$ century that recognizably modern forms of democracy — based on universal suffrage, referendum and recall, "public ownership and sovietic governments"-emerged in the West. Scholarship about the dark side of the Renaissance, slavery and colonization, and the limits of the Enlightenment has only emerged recently but it is supportive of Sarkar's scepticism about the democratic claims of the West. For Sarkar the mainstream Western liberal scholars in his time were making exaggerated and untenable claims about Europe's early and unique path to democracy. Besides, they did not take note of the fact that empires in India and China were too large for despotism to work effectively. His principal argument was that

the political psychology of the Orientals has been pragmatically uniform with that of the Occidentals both in its strength and limitations. In approaching the East, therefore, in the future the West should not attitudinize itself as to an antithesis, as it was the custom during the last few decades, but as to a "double" or replica and analogue. (Sarkar 1919a: 58) $)^{10}$

9 Sarkar's methods for raising living standards included not only capital and technology but also cottage industries (Sarkar 1926: 402-404).

${ }_{10}$ Sarkar observed that in the three centuries after Alexander's accession to the Greek throne "race-boundaries were being obliterated, cultural angularities were 


\section{Hinduism and Buddhism}

Sarkar writings about Hindus and Hinduism have generated much debate. Benjamin Zachariah has linked his ideas to a "fascist repertoire" because of his concerns about the recent rise of the Hindu right (Zachariah 2015a: 610). One needs to look more closely at the specific arguments that Sarkar made, particularly against the distorted view of Indian society and the Hindus popularized by Max Mueller and Schopenhauer. In Hindu Achievements in Exact Science published in 1918 (Sarkar 1918c) and The Positive Background of Hindu Sociology published in 1914 Sarkar emphasized the "secular, worldly and 'positive' elements of Hindu social economy" (Sarkar 1914a: x). ${ }^{11}$ The contemporary Western perception of the Hindus as other-worldly people was erroneous. The Hindus had discussed everything"from the tamarind to the pole-star" and their literature grappled with everything from "sex to salvation" (Sarkar 1937a: 4). Sarkar emphasized in several instances the synthesis between spiritual and secular values citing the Raghuvamsha of Kalidasa, "the Machiavellian Kautilya shaking hands with the Nirvanist Sakyasimha. Here are secularism and otherworldlyism welded together into one artistic whole, a full harmony of comprehensive life" (Sarkar 1937b: 363).

Sarkar rejected the claim of many compatriots who genuinely believed that India was more advanced spiritually than the West. He argued that the tradition of mysticism was equally strong in the west with figures like Pythagoras and Plato, St. Paul and Plotinus, Pascal, Bunyan, and Blake. In his judgement pessimism was not only a characteristic of eastern religions. It was clearly present in the Books of Job and Ecclesiastes in the Old Testament, in Greek tragedies as well as in the New Testament with its 'emphasis on the 'sins' of the 'world' and

\footnotetext{
being rounded off, people's intellectual horizon was being enlarged, and the sense of universal humanity generated" (Sarkar 1916b: 99).

${ }^{11}$ He also applauded the 'materialism and energism' of Swami Vivekananda, the founder of the Ramakrishna Empire (Sarkar 1942a: 168).
} 
the "flesh"" (Sarkar 1937a: 24). Also, the portrayal of Buddhism as a pessimistic religion was contradicted by evidence. The Buddhists were also energists setting up hospitals, monasteries, and academies. Sarkar highlighted the difference between the views of Sakya, the enlightened one, and Buddhist religion that subsequently treated him as God. Besides, Sakya had "no monopoly as a theologian or moralist or spiritual doctor" in a period of pluralist efflorescence. Even if his teachings were pessimistic "they were not the sole source of light" in his time (ibid.: 26).

He believed that the essential element of the Vedic literature was "secular" and it had a "pre-eminently martial character" (Sarkar 1937a: 303). ${ }^{12}$ Sarkar found socialistic, humanist and democratic elements in the Vedic period of Hinduism and in subsequent periods as well (Sarkar 1937b: 469-475). Sarkar believed that the Vedic polity was not that of the chieftain and the priest but of "the vis, the demos, the mass." Vedic life was pluralistic and had "democratic and secular" elements (Sarkar 1937b: 129, 131). He argues that

it is not so much the Varnasrama as the protests against the Varnasrama, not so much the law and order, as the violations of law and order, not so much the alleged pure races or castes as the varna-samkaras, the «mixed colours», fusions of ethnic elements,or rather the simultaneous operation of these two sets of forces that constitute the norm of Hindu cultural evolution. (Sarkar 1937a: 344)

Sarkar's idea of religion is shaped by his views about human nature and 'psycho-social personality.' There is a perpetual fight between dharma and adharma, good and evil. In Chinese Religion Through Hindu Eyes, Sarkar opines:

${ }_{12}$ Sarkar writes: "A prosperous territory and a happy home, success over the enemy and expansion of dominions, - this is what the Hindus wanted in the Vedic age. Their literature portrays, therefore, the worldly interests of men and women" (Sarkar 1937a: 304). 
Comparative Anthropology and Comparative Psychology will show that man has everywhere and always been fundamentally a beast, and that beneath a superficial varnish of so-called culture the «ape and tiger» hold their majestic sway,_- giving rise to superstitions, prejudices, idols and avidyas under different guises and conventions. The brute-in-man is a fact,- - the datum; but the god-in-man is only an idea,- - the ideal to be realised. (Sarkar 1916b: xiii)

He believes, "the hate-love, competition-cooperation, himsa-ahimsa, war-peace dualities of every mental pattern may be regarded as the first postulate in social psychology" (ibid.: 502). The world is always governed by the polarities of dharma-adharma. Sarkar believed that a straightforward conflict between dharma and adharma, between good and evil, in which the good eventually wins was a misreading. He opined,

a definite goalfulness cannot be maintained as the nature of human remakings or societal transformations. Nor can a final annihilation of evil or adharma be demonstrated to be in the nature of social evolution or human destiny. I have therefore argued as much against the Hindu Gita and Upanishat theories of progress as against the Western theories from Condorcet, Hegel, Marx and Comte to Lenin, Spengler, Hobhouse and Sorokin. (Sarkar 1941: vi-vii)

Progress was endless and the struggle between good and evil created disequilibrium. Youth as the 'embodiment of creative disequilibrium' had the capacity to remake mankind but, by his own logic, not permanently. This interpretation of the texts, which were widely discussed in intellectual and political circles of his time, differed from those of his contemporaries and put him in a class of his own (Kapila and Devji 2013).

Sarkar's interpretations of Hindu religion and caste are based on the scholarship of his time, the concepts he borrowed from various academic disciplines and the new terminology he frequently coined. So, his understanding is dependent on the evidence that was available to him but also the theories or concepts that he chose to deploy. On this basis he came up with arguments denying the frequently cited textual 
interpretation of the Purushasukta hymn about the fourfold caste hierarchy. More importantly, Sarkar questioned the social and historical impact of this text and the textual approach to the question of caste in general. He argued that the four-fold division of society in authoritative works down to that time was, "like Plato's classification, a 'legal fiction" more than a reflection of social reality" (Sarkar 1916b: 205). On this point Sarkar is in good company-normative texts are no longer taken as a reliable source for studying social reality.

Sarkar argued that the Purushasukta hymn in the Rgveda has "two or three logics in one and the same sukta." In the sukta the navel (and correspondingly the air) is mentioned as being superior to the head (and correspondingly the sky), the head (sky) as superior to the feet (earth) and feet (earth) as superior to the ear (four quarters). Writes Sarkar: "The question of precedence or superiority of some in relation to the others cannot be said to arise in the enumeration, illogical and incoherent as it is" (Sarkar 1937b: 138). The Shudra is not a non-Aryan in the cultural and social sense or else he has been accepted in that 'societal organization' even if he is a non-Aryan. Sarkar goes on to argue that Shatapatha Brahmana [III, 2; I, 39-40] shows that the Vaishya is equal to the Brahmana and the Kshatriya. The historian U. N. Ghoshal, however, strongly disagreed with Sarkar's arguments (Ghoshal 1927: 625-658). ${ }^{13}$ According to Sarkar the Vedic texts were not about the life of the Aryans alone. As the Aryans were pastoralists averse to 'manual professions' they had to meet the original inhabitant's half-way. Therefore, Vedic polity was marked by 'interracial and intra-racial conflicts' as well as race-cooperation and hybridity based on inter-dependence (Sarkar 1937b: 144-145). In Sarkar's view the Atharvaveda could have been "originally the Veda of the Vratyas" (ibid.: 148). The incorporation of the Vratyas to the Brahmanical fold was the incorporation of Aryan communities into the Brahmin community (ibid.: 146). (ibid.: 633). 
In a period of warfare and changing political fortunes "individuals of lower castes could [thereby] get themselves admitted as $\mathrm{Ks}[\mathrm{h}$ ]atriyas, Brahmanas and what not" (Sarkar 1937a: 130) ${ }^{14}$ Sarkar asserted that before the Muslim invasions in the $13^{\text {th }}$ century the history of races was more important than the history of castes in the study of social classes. The terms Brahmin and Kshatriya applied to different races and tribes in the earlier period. The eugenic aspect of caste-based on regulation of marriages - emerged after the $13^{\text {th }}$ century and led to proliferation of innumerable castes. In earlier periods recurring warfare and political turmoil led to the shifting fortunes of "localities, tribes and families." In the Vedic period or in the Mauryan, Andhra, Kushan and Gupta period or even the Vardhana, Gurjara-Pratihara, Pala and Chola societies the caste system did not exist in the form prevalent in the early $20^{\text {th }}$ century. Sarkar argued that political and military changes produced "a regular "convection-current" throughout the socio-economic system, making the elevation and depression of castes exactly parallel to that of races the leading classes of one age being the depressed classes of another, and so on." Warfare has affected the history of races and classes everywhere.

In each case of socio-economic transformation brought about by military-political revolutions the new orders have tried to preserve the old «legal fiction» by affiliating themselves to the traditional orders. The dynamic principle of 'progress' has thus been in operation in each synthesis, though the statical principle of 'order' has never been lost sight of. (Sarkar 1916b: 206)

Sarkar was a cosmopolitan Hindu who used the term Hindu in a very broad sense. To him the people of Mohenjo-Daro were as much Hindus as those of the Vedic period. Hinduism, Buddhism and Jainism were more or less indistinguishable

${ }_{14}$ Kshatriya status could be acquired by accepting the profession of arms (Kolff 2002). 
for him. ${ }^{15}$ Although he admired the Vedas and the Upanishads it is Puranic Hinduism that he found closest to modern Hinduism and it is this religion of the heart that he identified with strongly. He argued that there was no Buddhist India or for that matter Buddhist China or Japan. Sarkar's celebration of a common Asian mentality and religious consciousness certainly constitutes an Asianist vision "that originated in the subcontinent itself." In Carolien Stolte's survey of four Indian cartographies of Asia that were "driven by locally shaped agendas" (Stolte 2016: 51) Sarkar does not figure among the personalities discussed. Elsewhere, Stolte and Harald Fischer-Tiné have argued that Sarkar rejected ideas of "civilization" and "cultural community" and for him "Asian solidarity represented solely a temporary and goaloriented bond in the battle against the hegemony of Eur-America" (Stolte and Fischer-Tiné 2012: 91). According to the authors Sarkar, by constructing a vision of a "benevolent colonialism"- Greater India thesis - "takes up the contemporary European rhetoric of "development" or "mise en valeur" and seeks to trump it" (ibid.: 92). In their general survey of the discourse on the Greater India and Asian solidarity the authors do not address Sarkar's intellectual engagement with religion and culture.

Writing in 1916 Sarkar dedicated his book on Chinese religion to the three scholars who spread Hindu-Buddhist culture and religion in the East - the Indian Kumarajiva, (405 AD), the Chinese Hiuen Tsang (602-664 AD) and the Japanese Koba Daishi (774-835). Writes Sarkar: "The original Chinese ideas on every subject began also to be transformed, re-interpreted and Hinduised. The Augustan age of Chinese Culture was thus the age of a thorough-going Indianisation of China" (Sarkar 1916b: 252). Sarkar went so far as to claim that, "Hindu Dhyana or meditation is the chief characteristic of this re-interpreted Confucianism"

${ }_{15}$ Writes Sen: “The racially open Hindu nation could be a hair's breadth removed from the swallowing nation, threatening the identities — and inevitably, the rights — of those on the margins" (S. Sen 2015: 81). The case for common religious beliefs and mentality needs to be assessed as an intellectual argument as well. 
(ibid:: 254). Kumarajiva introduced Mahayana sutras and the texts of Nagarjuna into China. Also, according to Fan Muyou, Kumarajiva translated the Vimalakirtinirdesa which "reflects a dialectical interaction between his own thinking and that of the Chinese philosophical context in which he worked" (Muyou 2016: 78) ${ }^{16}$ As is evident from "The Beginning of Hindu Culture as WorId-Power (A. D. 300-600)...," a chapter from his book on Chinese religion, Sarkar was seeking a place for India in world history and for Hinduism as a world religion. Scholars interested in comparative religion and intellectual trends may consider Sarkar a pioneer in their field despite specific disagreements. ${ }^{17}$ Hermann Kulke has cited the similarity in the views of Max Weber and Jacob Cornelis van Leur comparing Hinduization abroad to the mediaeval German influence in the east. In a concluding remark van Leur repeats this comparison: "One must imagine that Southeast Asia was 'Hinduized' in the same way the German civilization of the middle ages extended its influence far beyond the limits of German group colonization, in the same way the Graeco-Byzantine hierocracy set its stamp on the civilization of Russia" (Kulke 1993a: 260).

Sarkar's excessive claims about the "Hinduisation of Asia" do jar sensibilities but he does not identify himself strongly with the mainstream Indian nationalist framework which was "essentially an imperialist history for Southeast Asia" (Basha 1998: 405) ${ }^{18}$ Broadly speaking, Indian influence abroad was not primarily based on military conquests or political domination or concepts of a "superior" race. ${ }^{19}$ According to Sarkar

${ }_{16}$ Buddhist teachings spread throughout Asia based on "localization and selective adaptations" as well as reverse transmission of ideas from peripheral to core regions (T. Sen 2010a: 35-36).

${ }_{17}$ For ideas of Muslim cosmopolitanism and universalism see Alavi 2015 and Devji 2015.

${ }_{18}$ Kishor Basha points out that there is a difference in the attitude towards Indian influence in Southeast Asia in the pre-nationalist writings of R. G. Bhandarkar and that of R. C. Majumdar in the nationalist phase (Basha 1998: 405).

19 The Chola naval campaign against Srivijaya in 1025 was "a unique event" in the otherwise peaceful relations between India and Southeast Asia (Kulke 2016: 64). Kulke 
Hinduisation was "the transmission of a new life and a new love from an equal to an equal. An 'age of chivalry' was that" (Sarkar 1916b: 256). Recent scholarship partly endorses his views. Tansen Sen argues, "While it is true that commercial and cultural exchanges during the premodern period mostly took place without a hegemonic power, there were times when states took punitive actions to express their desire to control or profit from cross-regional interactions" (T. Sen 2010b: 998). Besides, there was Chinese interest in Indian sugar making technology and Brahmin medical texts and in manufacturing longevity drugs before the $8^{\text {th }}$ century (T. Sen 2001: 10, 16). On the basis of the fact that "the term 'Zhongguo' simultaneously denotes China and the Buddha's country, Magadha, in Chinese historical documentation" Tan Chung has argued that India and China have been "Buddhist twins" for twenty centuries until recently (Chung 2009/2010: 4). The term Zhongguo/ Middle Kingdom is not Sinocentric but arguably Indophilic. ${ }^{20}$

According to Sarkar, "Asiatic religious consciousness has (thus) evolved everywhere the same idea of 'Cosmic Order' or 'Permanent Way' as the keystone of man's spiritual life." Even before the advent and spread of Buddhism India, China and Japan had a shared religious consciousness (Sarkar 1916b: 275). This common mentality was traced using the works of Chinese, Japanese and western scholars like Kume, Harada, Okakura, Aston, Johnston, Edkins, Beals and Werner. On the basis of his studies Sarkar claims that in the religious life of the Far Eastern people the 'individuality' that John Stuart Mill lauded was clearly present (ibid.: 262). The unity of the Asians was based on three factors: faith in an Eternal Order, or a sanatana way, in pluralism and in

has called the Devaraj Cult a "state cult of the Hindu middle ages of Southeast Asia" (Kulke 1993b: 327).

${ }^{20}$ The "successful transmission of Buddhism from India to China" and the designation of India as Western Heaven by the Buddhists created a favourable impression of India in China. Writes T. Sen, "Although not widely recorded in Indian sources, the steady stream of missionaries, magicians, doctors, astronomers, and profit seekers from India to China indicate the equally approbatory image of China in South Asia" (T. Sen 2001: 23). 
toleration. As nature-worshippers they can never be monotheists. Unfortunately, enthralled by monotheism as a sign of modernity Asian scholars "have fallen an easy prey to this superstition" (ibid.: 277). Sarkar claims that "monotheism is a psychological absurdity. Both the physical organism and the nervous system of man predispose him to be a polytheist" (ibid.: 277). Man, a sincere pluralist in worldly matters becomes a hypocrite in other-worldly matters by professing monism or monotheism. Belief in pluralism is shared by Taoists, Vedists, Buddhists, Shaivas and Shintoists in Asia. Their beliefs are "essentially composite, pluralistic, polytheistic-with a monistic or monotheistic under-current" (ibid.: 278).

The spirit of toleration in Asia was the outcome of this pluralism. Polytheists are never bigots or fanatics. Propounds Sarkar, "What Socialism is in the economic sphere, what Republicanism is in the political world, that is Polytheism or the Cult of the Many in matters spiritual or religious" (ibid.: 279). India, China and Japan had a common religious mentality. He wrote, "Fundamentally the worshippers of world-forces, the Hindus like the Chinese can manufacture a god every ten years" (ibid.: 119). ${ }^{21}$ Interestingly, Sarkar makes the claim that both philosophically and historically Neo-Hinduism and Sino-Japanese Buddhism are similar and their adherents are co-religionists. He rejects the argument that Buddhism was strangled in India. The disappearance of Buddha from the consciousness of contemporary Indians was comparable to that of Vedic deities. Contends Sarkar, "And if in spite of this the Hindus have a right to be called followers of the Vedas, they have equal claims to be regarded as Buddhists (both Hinayana and Mahayana)" (ibid.: 283).

\section{Nationalism and the Indian nation}

In a publication on the 'science' of history in 1912 using the 'philosophicocomparative method' Sarkar tried to elucidate the "laws or generalizations

${ }^{21}$ Discussing the god-lore of India and China between B. C. 350-100 Sarkar observed: "the people were inventing new deities exactly like the Chinese" (ibid.: 118). 
that may be deduced out of the facts of universal history" (Sarkar 1912: v). Only a study of the "array of world-forces' shaped by the "mutual intercourse' between several people at multiple levels can tell us about any one people (ibid.: 23). He believed that the history of nations or nationalities could only be understood in a wider context and never in isolation. Over the next three decades his views on nationality evolved shaped by his understanding of war, imperialism, fascism, and the Indian national movement. He had a lifelong fascination with youth as the "embodiment of creative disequilibrium" and their capacity to remake mankind. These observations explain Sarkar's recurring appeals to Youth and to Young Asia (Sarkar 1941: vii). For someone who has written about the energism of the Hindus, even during the periods of history when they were ruled by foreigners or people of other faiths, Sarkar has a substantially pragmatic view of nations and nationalism. In a lecture in 1926 he wrote:

For all practical purposes there is hardly anything as the nation. A nation is an abstraction. But there is such a thing as the agricultural labourer. There is the jotdar, there is the aratdar, there is the boatman. There are clerks, school masters, industrial workers, bankers, Zemindars and so on. (Sarkar 1938a: 59)

When he claimed that despite the existence of caste there were class distinctions in India comparable to those in the West what he had in mind was a hierarchical occupational structure and income and wealth differentials. In 1942 Sarkar observed, "The distinction between the 1000-2000-Rupee Brahman and the 150-500-Rupee Brahman or the 50-150-Rupee Brahman is no less profound than the distinction between the 2000-dollar American and 500-dollar American or the 50-dollar American" (Sarkar 1942b: 259). The might of money ruled inter-human relations and public life regardless of whether the people were Hindu or Muslim, nationalists, socialists or communists. Nationalism could not be just the expression of the peculiar "genius" of a people.

Presciently and realistically Sarkar had asserted, in the Politics of Boundaries first published in 1926, that "nationality is a very young 
phenomenon both as a concept and as a fact" (Sarkar 1938b: 4). Rejecting cultural ideals as the basis of nationality he had argued that all over the world the "advancement of the happiness of human beings" was a common ideal or slogan (ibid.: 8). Moreover, the cultural institutions of the world were getting to be more uniform. Never in history had there been ethnic or cultural units that had functioned as a "self-sufficient economic entity." Nor was it possible in his time. He declared, "No innate motive force impels a race, language, religion or Kultur to embody itself in a statal organization such as would be its own characteristic expression" (ibid.: 11-12) There was "no natural and necessary connection" of the boundaries of the state with culture, religion, language or race" (ibid.: 15).

According to Sarkar, nationality was the "physical (territorial and human) embodiment of political freedom, maintained by military and economic strength" (ibid.: 21). As the nation was "an artificial corporation brought into being by the fiat of human creativeness" neither homogeneity necessarily produced strength nor heterogeneity engender weakness (ibid.: 21). The more debatable claim in Sarkar's assessment of nationalism is that "historically speaking, nations are born in wars and wars only." 22 He claimed, "Genetically, therefore, nationality is in essence a militaristic concept. If there be any spirituality associated with nationalism it is the spirituality of war or the categorical imperative of Kshatriyaism" (ibid.: 16). This conclusion was based on his reading of the wars that led to the unification of Italy and Germany and the creation of new nation states after the First World War (Sarkar 1942a: 299). Sarkar anticipates the argument about the modernity of nationalism but he accepts neither language nor race as sufficient or essential for the emergence of a nation state as postulated by Benedict Anderson or Anthony Smith respectively (Anderson 1983, Smith 1986).

${ }_{22}$ Sarkar asserted, "No war, no science. No war, no technocracy. No war no progress. No war, no civilization." These statements about war as a social force were not to be treated as deterministic (Sarkar 1942a: 187). 
In view of the changes in the world economy Sarkar believed that nationalists would have to reformulate their philosophies to cope with the "new era of interdependence, mutual exploitation and world economy" (Sarkar 1938a: 76). He advocates polyglot, multi-racial and hetero-cultural states. He believed that if Germany had won the First World War, they would have redrawn the boundaries of states in Asia and Africa as ruthlessly as the Allies had done in Central Europe. He was critical of the League of Nations which had created a body of states rather than of nations. Many countries created at the end of the First World War had large ethnic and linguistic minorities.

The world knows not a League of Nations, which is a misnomer, but a League of states, which is a reality. Every state is to be postulated as a complex of multiple races, diverse languages, and plurality of cultures. The nationality theories of Herder, Fichte, Mazzini, Kossuth, Masaryk and Aurobindo, deserve to be treated as curios of political philosophy. (Sarkar 1942a: 241)

Sarkar is an expounder, interpreter and representative of the Hindu faith and tradition. He is aware of the "transcendentalised positivism of the makers of Hindu civilization" (Sarkar 1914a: xi) and despite different political codes or Nitishastras in different regions of India "the oneness and basic uniformity of Hindu life throughout India" (ibid.: 7). He claims that his own study of the Gambhira festival associated with Shaiva-cum-Shakta worship in Bengal revealed the unity underlying the diversity of customs or of diversity superimposed "upon a fundamental bed-rock of uniformity" (ibid.: 15; Sarkar 1917a: 23-26). Zachariah finds The Folk-Element in Hindu Culture "intimidatingly technical and opaque" but asserts that its basic arguments can be linked to right wing populism (Zachariah 2015b: 649). He has argued that "the same terms might actually refer to different concepts, and similar concepts might be rendered by different terms" (ibid.: 644) but it is not clear that Sarkar's analysis of folk religion is sufficiently similar conceptually to the volkisch ideas that emerged in Germany. Sarkar's objective 
was to understand the relationship between the Sanskrit texts and vernacular literatures - "the translation of higher cultures into the tongues of the people" and the local adaptations and cultural rapprochements based on all India Hindu traditions (Sarkar 1917a: 24).

Zachariah's characterization of the idea of Greater India as a "spiritual lebensraum" (Zachariah 2015b: 650) ignores the spiritual dimension and cultural ethos that has been discussed earlier. If claims about proselytization by themselves were sufficient ground for being included in a fascist repertoire it would also put many spokesmen of proselytizing religions in India in a similar bracket. This would offend those liberals who believe in the freedom to propagate religion as well as those who value a religious life (Dhammadipa 2015). Also, if Sarkar readily acknowledged the role of foreign cultures on India (Sarkar 1917b: 212) the impact of Hindu-Buddhist culture on other countries cannot be adjudged a sign of chauvinism although he often blew his trumpet too loudly.

A recent study has pointed out that Sarkar "challenged the racist grammar of difference that imperialism had established in Asia and Africa" but he also "re-appropriated the category of race to serve the militant nationalism he thought to be indispensable for India's struggle against the British Raj" (Six 2018: 439). But one needs to recognize some complexities in his views on race. The relationship between races had evolved over centuries and there were no pure races as virtually all had at different points of time adjusted with and adapted to each other. The capacity for assimilation was a product of the "elemental instinct of self-preservation" throughout the world (Sarkar 1916b: 193). Asserted Sarkar, "And the race-psychology of the Tartar, the Jew, the Briton, the Pole, the Hindu, the Pathan, the Chinese, the Bulgar, and the Slav displays the same assimilative capacity for utilizing new conditions and thus growing by adaptation as that of the Far Eastern people" (ibid.: 193).

While emphasizing the role of the Japanese in the programme of "de-albinization, i.e., the overthrow of white, albinocratic hegemony in non-white lands and seas" Sarkar recognized that "a purely ethnic war, i.e., war of races in which all non-whites are arrayed against all whites 
has never been and can hardly ever be a fact of Realpolitik." Recognizing that de-albinization is not 'de-imperialization' he noted that it may not be "more than the replacement of white empires by Japanocracy in certain regions of Asia and Africa" (Sarkar 1942a: 305-306). This scepticism about Japan was expressed when he was apparently openly attached to Nazism (Zachariah 2015b: 645). Satadru Sen has rightly argued that Sarkar's respect for the Hitler state was tempered over the 1930s (S. Sen 2015: 158).

Sarkar does not adhere to the narratives of either Hindu nationalist or secular liberal historians. He argued that "Islam was regarded in India by the people who encountered it for the first time, primarily, and for a long period, solely, as an alien system of socio-religious faith and institutions" (Sarkar 1917a: 215). He compares Muslim expansion in India after the tenth century with "the nature of previous Tartar settlements or still earlier Aryan colonisings. The conflict of the Hindus with the new-comers was certainly very bitter like that described in the Vedic literature as having taken place between the Indo-Aryans and the aboriginal Dasyus" (Sarkar 1916b: 201). As the Hindus were unable to "openly profess" their religion during the period of Muslim "supremacy" they resorted to "various tricks" to do so. Writes Sarkar, "Thus they introduced the worship of Satya Pira [Satya Pïr] (a Mohammadan saint), which was only a pseudonym for their own 'Narayana' or Visnu" (Sarkar 1917a: 220). This is the very same cult that has been regarded in recent secular scholarship as evidence of syncretism or Bengali translation of Islamic ideals (Stewart 2000: 21-54, 2001: 260-287). ${ }^{23}$

Sarkar believed that India had never been subject to a "foreign power" and that "Islam as a political factor" had not interfered with "the national independence of the people of India." Also, Islam had never been paramount throughout the country as Hindu kingdoms had coexisted with Muslim states for centuries, particularly in South India. Besides,

${ }^{23}$ For the competition between Hindu and Muslim religious figures in medieval India see Alam 2004. 
the relations between the Mohammedan states and the original Hindu states, or between the Mohammedan Empires and their Hindu citizens, or between the Hindu Empires and the new Mohammedan citizens did, at their worst, but repeat the story of the relations between the Roman Catholics and Protestants in the West. (Sarkar 1918b: 484)

Sarkar regards the Hindu and Moslem rulers of the precolonial era as secular because there was no theocracy ever in India. In recent explorations of the meanings of secularism Sudipta Kaviraj has argued that the history of other cultures cannot be turned "into an endless waiting for the recurrence of the history of Europe" (Kaviraj 2016: 158).

Rajeev Bhargava has suggested that there might have been in India "a complex of movements leading to diverse secular ages spread across several centuries and across many regions" (Bhargava 2016: 208).

According to Sarkar, accounts of the slaughter and persecution of Hindus could not arouse Hindu sentiments against the Muslims "for the oriental student can easily cite plenty of instances of inquisition, torture and pogroms in the annals of Christendom." He argued that "the crusading zeal of Islam was felt to their sorrow by the Christian powers of Europe not less than by the people of India, and that for centuries the Mediterranean Sea was no less a Saracen lake than was the so-called Arabian Sea." Reflecting his preoccupation with the martial qualities of the Hindus Sarkar goes on to state that "the fact that they were conquered by Moslems is not more disgraceful to Hindus as a race than to Europeans" (Sarkar 1919b: 648).

The "naturalization of Saracenic culture" in India led to a Renaissance as brilliant as that under Vikramaditya, the great ruler of the Gupta period. The period between 1550 and 1700 was marked by "Mahometans Hinduising and Hindus Islamizing in every department of life" (Sarkar 1916b: 202). Abul Fazl, the author of the $\bar{A}$ ' $\bar{n}$-i Akbari, wanted to "function as a bridge between the two great religions, to be a peace-maker" (Sarkar 1935: 247). He was a "great precursor" of the Hindu Rammohan Roy of the end of the $18^{\text {th }}$ and the early $19^{\text {th }}$ centuries. (ibid.: 248). Sarkar also commends Abul Fazl's endorsement of the fourfold Hindu social stratification. Anyone familiar with the Hindu 
Artha, Smriti, and Niti Sastras would recognize that "Abul Fazl is reproducing the most fundamental concept of the king's functions vis-à-vis Chaturvarnya (the four-ordered social polity)" (ibid.: 251). Abul Fazl argued that images were used by the Hindus to prevent the thoughts of the people from getting distracted during prayer. Sarkar commends his "propaganda of inter-religious understanding and inter-racial peace" (ibid.: 255). Sarkar's own eclecticism or cosmopolitanism is evident in his acknowledgement that the Renaissance in India and China and other parts of Asia was "in certain cases the joint work of Hindus or Buddhists and Mussalmans" (Sarkar 1937c: 174).

Sarkar also propounded a theory of the "contractual basis of racial amity." Only after both Hindus and Muslims had become "fully conscious of their differences and individualities" would they be able to establish cordial relations. State and society were not organic entities but formed on a contractual basis. He concluded thus:

It is this element of contract such as one finds in the establishment of a manufacturing company or business organization or educational institutions that will begin to operate in the mentality of the Hindus and Mussalmans as soon as each party is conscious of its own wants and limitations as full-fledged moral agents. (Sarkar 1938a: 96)

It is Sarkar's understanding of the contractual basis of amity which allows him to celebrate simultaneously the achievements of the Marathas against the Mughal rulers as well as the development of a Renaissance under the Mughals. He asserted, "Like Abul Fazl the Hinduized Moslem, Sivaji was to a certain extent a Moslemized Hindu, both being true indices to the Indo-Saracenic Renaissance of the times" (Sarkar 1937b: 506). Sarkar commends the cultural nationalism of Sivaji who consciously wanted to restore "Hindu political dignity to its ancient or rather pre-Moslem conditions." He is hailed as a "Hindu avatara of the seventeenth century" (ibid.: 507-508). As an "exponent of national language in politics Sivaji can claim recognition as one of the first among the modern makers of history as a precursor of Herder (1744-1803) 
and Fichte (1762-1814)" (ibid:: 511). Linguistic nationalism flourished under Shivaji leading to the Sanskritization of Marathi. There is no discrimination against the Moslems or their religion in the teachings of Ramdas, the preceptor of Shivaji. The idea of mahārāștradharma $b \bar{a} \underline{d} h v \bar{a} v \bar{a}$ is "essentially secular and territorial" and Ramdas is the "first conscious exponent of linguistic nationalism in India" (ibid.: 575).

Historians who look at the relations between Hindus and Muslims also have to grapple with his views on pluralism and the concept of Śakti-yoga, energy or force, the 'very deity' for Indians. He is able to praise in the same breath Saiyad Jamaluddin as the proponent of Pan-Islam and Dayanand Saraswati as one who declared war against the missionaries of Christ, B. G. Tilak as a patriot who invoked the Gita, the "Bible of mystical militarism" and Kali Charan Banurji as the symbol of an "Indian Christianity" free from European domination (Sarkar 1939: 301-302). He also goes on to commend Madhu Sudan Dutt's Meghnadvadh for weaving together the 'folk-spirits' of the Hindus, Muslims and Christians and creating "the Greater India of rapprochement between the East and the West" (ibid.: 314). The way forward was a "conscious cultural rapprochement" when Sanskrit knowing Hindus would learn Arabic and Arabic knowing Muslims gain proficiency in Sanskrit. If Benares Hindu University encouraged experts to study Muslim achievements in Medieval Culture it could create the basis of "a new Islamic renaissance" (ibid.: 331). He argued that mysticism could flourish anywhere: "The Sufism of medieval Persia, the Zen(dhyan)-ism of mediaeval Japan, the Yogaism of Mediaeval India, the transcendentalism or romanticism of Young Germany, and Carlylean mysticism, are all birds of a feather" (Sarkar 1916a: 57, 83).

Sarkar has noted that owing to the disparity between the Hindus and Muslims in Bengal there was a lack of amity but there was a wide spectrum of trends from the extreme left to the extreme right as among the Hindus (Sarkar 1937a: 474). Referring to the orientation of Moslems to "ancient Islam," Muslim contributions in the medieval period, he argues that it does not constitute a return to the past but "the cultivation of nationalism on the one side and of visva-sakti (world-forces) on 
the other." This is similar to the "double quest of modern India from Rammohun to Gandhi." He believes that "it is the spirit of Moslem positivism in science and historiography that they are trying to restore" in order to grapple with problems of modern life. This is acclaimed as a genuine Renaissance and Sarkar regards the reinterpretation of Islam "as a plank for "futurism." Far too optimistically he asserts that "the ideological foundations of a deeper solidarism between the Hindus and Mussalmans are thus being laid wide and deep in Bengal" (ibid.: 475-476). He admired the initiative of the Osmania University in Hyderabad to impart higher education in Urdu and to promote translations from foreign languages into Urdu (ibid.: 500). ${ }^{24}$ The attitude of Sarkar was that most movements of consequence were Januslike: "nationalist, traditionalist or revivalist on the one hand and at the same time internationalist, modernist and reformist on the other" (Sarkar 1937a: 524).

Benoy Sarkar staunchly believed in the distinctive importance of Bengal as well as all other regions of India. Historians have long noted the ambivalence among many prominent figures, pulled in different directions, because of their attachment to language, religion or region. Competing basis of identity formation can only be understood contextually (Jalal 2000). Sarkar wondered why twenty language groups could not be treated as distinct nationalities in India. Controversially he propounded in 1922:

The present map of India, hodge-podge as it is, is the greatest superstition of Indian patriots; the fallacy of their political writers consists in trying to envisage future state-making on the lines of the map that has been artificially created by the haphazard annexations of the British since 1757. (Sarkar 1922: 344)

In 1942 in the context of the Cripps Mission proposals he argued that it was a "bitter truth" that India like Europe was not one and could not be

${ }^{24}$ Also see Sarkar 1939: 326. For a recent appraisal see Datla 2009. 
unified (Sarkar 1942c: 104). As he stated even in 1943 in The Equations of World Economy, Bengal "deserves to be treated as an independent economic unit just as the Bengali people is known as an independent culture-unit." He wanted Indian economic planning to be worked out on a 'provincial basis' but he also went on to argue that "the place of the Bengali people (60 million) in the Indian complex is to be envisaged as similar to that of the French, Italians, Germans, etc. in European polity" (Sarkar 1943a: 196). In his view all the Indian provinces ought to try and make themselves "autarchic in the first instance, and then look for All Indian co-ordination, centralization or federalization according to requirements" (ibid.: 197).

Soon after India gained independence, however, Sarkar called for a reinterpretation of history, medieval as well as modern. He urged the abandonment of the "obscurantist and reactionary orientations" of those who were living in the epoch of Shivaji and Aurangzeb (Sarkar 1949: 153). India did not need a single national language like Hindi. Equally, creating "linguistically homogenous provinces" based on Bengali or Marathi was "a wild goose chase." The Herderian doctrine of the "linguistic nation" had become obsolete (ibid.: 155). The fetish of provinces would have to be abandoned and they were to be treated as districts. It would be wise to support a "unified, consolidated and centralized India from top to bottom and in every possible sector" (ibid.: 157). He predicted that the federal principle would be replaced by "thorough-going unification" and "administrative centralization" and believed that the Bengali intelligentsia would play an important role in this process (ibid.: 117).

\section{Authoritarianism and cosmopolitan internationalism}

Sarkar was preoccupied with issues of race and eugenics and authoritarian ideas about the education of people. Satadru Sen has argued that Bhudev Mukhopadhyaya represented an "aborted conservatism" in which Hindu identity was important without an anti-Muslim animus. His modern conservatism "could partake of discourses that were rhetorically 
opposed and produce something substantially new" (S. Sen 2017: 364). Sarkar, hardly a rakshansheel like Bhudev, also did not have any antiMuslim bias. He was more assertive and sought much wider social transformation which included the need to educate, train and discipline the people. Writing in 2001 Zachariah explored the conservative and right-wing ideas about race and elite control in the discourse on development in India. Cutting across ideological lines- the Congress party's Planning Committee, Fabian socialists, John Maynard Keynes and P. C. Mahalanobis were preoccupied with eugenics and discipline to promote development (Zachariah 2001). Since then Zachariah has widened his horizons to identify "forms of fascism" (Zachariah 2010: 197) not only in India but the entire world (Zachariah 2014). This article does not engage with this larger theme..$^{25}$ It argues that Benoy Sarkar cannot be compared to Tarak Nath Das or R. C. Majumdar or V. D. Savarkar despite certain common concerns (Zachariah 2015b).

The praise for Hitler in Sarkar's writings has to be discussed also in the context of his economic ideas. He frequently compared the impact of Soviet Five-Year plans on German planning (Sarkar 1942a: 119). He admired Italian corporatism, German economic recovery and Soviet growth rates at the same time. Maria Framke has rightly argued that in the debates on planning in India "ideological premises on which certain ideals of development were based were overlooked" (Framke 2013: 83). She has also cited Mario Prayer to argue that Benoy Sarkar valued "harmonisation of class interests without suppressing private initiatives" (ibid.: 94). Although he supported the role of great leaders and the state in nation-building he did not think India's economic development could be based on any of these models. In a lecture on industrialization in Bengal in December 1938 Sarkar observed that "the Indian people today is socio-economically incapable of a rationalized

${ }_{25}$ Emphasizing the importance of non-European contexts Hobsbawm argues, "European fascist regimes destroyed labour movements, the Latin American leaders they inspired created them" (Hobsbawm 1994: 135). 
planning of the Sovietic or of the German-Italian-Japanese type" (Sarkar 1942a: 146-147). ${ }^{26}$

Six has argued that Sarkar admired the fascists for their achievements partly because he was not interested in "social revolution" (Six 2018: 438) Also, Sarkar's pro-Nazi sentiment was "filtered through the language of scholarly internationalism." Writes Manjapra:

Sarkar's fascism was based on Hindu-Muslim unity within the cultural category of Bengaliness. And it is no wonder that Sarkar's great archetypal hero was Subhas Chandra Bose, who in 1941 began his campaign to both unify Hindus and Muslims and to destroy the British empire through close collaboration with Nazi and Axis powers. (Manjapra 2014: 209) 27 $^{27}$

Sarkar admired the Nazi regime as a benevolent dictatorship and was supportive of those who sought their help against British imperialism. ${ }^{28}$ Examining his ideas Satadru Sen has argued that Sarkar's fondness for Germany "bordered on delusion" although he considered the country part of the albinocracy (S. Sen 2015: 137). It must be noted that Sarkar compared the reparations imposed on Germany after World War I with the Indian experience of colonialism and the drain of wealth (Sarkar 1926: 51). Opposed to the imperialism and racism of both Britain and Germany he was willing to accept the emergence of Pax Germanica and Pax Japanica as "colleagues or rivals" of Pax Britannica and

${ }^{26}$ Also see Sarkar 1942d: 201. Much later Sarkar commented that India had become a "Doctor of Philosophy in socialism and communism as ideologies before she could effectively master the ABC of industrial economy and capitalism" (Sarkar 1949: 59).

${ }_{27}$ For Sarkar's respect for 'Field Marshal Bose' see S. Sen 2015: 33.

${ }_{28}$ Sen has argued that Sarkar's respect for the Hitler state was tempered over the 1930s (S. Sen 2015: 158). Also, Sarkar believed that militarism had to be "vested" in the people (ibid.: 162). In 1928 Sarkar recognized that fascism and Bolshevism were "but two aspects of anti-democratism in office" (Sarkar 1928: 320). 
Pax Americana with equanimity (Sarkar 1943b: 164). ${ }^{29}$ In Sarkar's reckoning in "the epoch of economic planning in the world economy" between 1933 and 1939 "technology and finance" were more important than ideological differences in accounting for rapid growth (Sarkar 1942a: 60-162). This is unacceptable to liberal imperialists as well as liberal internationalists.

Sarkar's Austrian German wife and his travels in Italy and Germany have only a limited bearing on his fascist sympathies. ${ }^{30}$ As Zachariah has pointed out he definitely linked Hindu ideas of conquest and power- of vijigisu and shakti - to those of Haushofer's general philosophy (ibid.: 303). However, it is also necessary to acknowledge his understanding of realpolitik and world-forces. Analysing the creation of Czechoslovakia in 1926 he had argued that "only through foreign intrigue and diplomatic assistance" can subject races achieve freedom (Sarkar 1938b: 20). Years later he noted how the Japanese challenge to Anglo-American domination had raised India's stature in international politics (Sarkar 1942a: 439). Under conditions of war between Great Powers "subject nations obtain chances for diplomatic higgling and negotiation with the old master." His realism was also robust enough to accept that Manchukuo was not much more than a vassal state (ibid.: 316).

Although Sarkar understood how India had been turned into a market for British goods, he still believed that foreign capital was vital for the regeneration of India. He argued: "However humiliating it might be to our national self-respect, yet under the present circumstances I am quite prepared to swallow foreign capital for a certain number of years" (Sarkar 1938a: 49-50) Sarkar recognized that foreign capital was "no unmixed blessing" but recommended negotiating reasonable terms with capitalists in Europe, America and Japan "on the principle

${ }_{29}$ Sarkar believed that Germany was not less "ethnocentric or raciological" than England or America (ibid:: 183-184).

30 The Sarkars "set an example for the possibility of transnational, decolonial families and communities" (Namakkal 2019: 141). 
that half a loaf is better than no bread" (Sarkar 1926: 395). He argued that "national sovereignty and foreign finance may go hand in hand" (Sarkar 1943a: 233). In 1949 although he thought that a 'world economy' based on 'interdependence' was getting stronger (Sarkar 1949: 36) despite creation of 'bloc autarchies' (ibid.: 38-39) - he also believed that a Third World War was bound to happen (ibid.: 26, 38). Above all he believed that India like other developing countries needed capital goods from the UK and USA and that it was an 'integral' part of the AngloAmerican economy (ibid.: 39-40).

Identifying an element of ressentiment nationalism in Sarkar's perception of Japan, Satadru Sen writes: "the insistence on a violent orient is part of Sarkar's attempt to restore Asia to world history by restoring history - imagined as the stuff of statecraft and expansionism - to Asia" (S. Sen 2013: 64). ${ }^{31}$ Sarkar observes a pervasive"spirit of revenge" in Asia because of the mal-treatment by Eur-America but asserts on the same page that the different nations "do not represent permanent divergences in Weltanschauung or outlook on the universe" (Sarkar 1939: 107). A staunch believer in the idealism of youth, Sarkar believed that Young India did not look back to the Mughal, Maurya or Gupta periods but "to a nobler and happier future of the human race." Young India was modernist or "futurist" (Sarkar 1916a: 88). The ideas of parity between East and West and his hopes for humanity place Sarkar in the league of cosmopolitan internationalists but his views about digvijaya, vishwashakti and matsyanyaya produced distortions and ambivalence (S. Sen 2015). ${ }^{32}$

He claimed he was only trying to understand "contemporary vishwashakti (world forces)" as "a non-political and non-party intellectual"

${ }_{31}$ Sen states that the need for revenge was to be valued in the colonies: "In the modern world, ressentiment is the only alternative to slavery and hegemony" (ibid.: 103).

32 According to Sen the task before nationalists was to "manage vishwashakti in accordance with Rassenkampf and matsyanyaya" (ibid.: 106). 
(Sarkar 1942a: 483). ${ }^{33}$ While the World War II was still raging, he thought the struggle between Germany and Britain for world domination would lead to another round of conflict "say, by 1960-65" (ibid.: 494). In 1941 he had declared that "a war of revenge may be expected by 1960" (ibid.: 203). This assessment also comes with a certain sense of personal identification with the fight against racism, imperialism and exploitation. Also, it is indicative of his rather exaggerated emphasis on race that he regarded the war between the Russians and Germans as "a race war" at bottom. It was not merely a fight between rival nationalisms, imperialisms and patriotisms (ibid.: 453). What he called the Asian Monroe Doctrine, which stood for Asia for Asians, was not an "unmixed blessing." He feared it might lead to the domination of neighbouring countries by Turkey and Japan. Insightfully he wrote: "It is an ambiguous category and may under circumstances turn out to be positively mischievous to certain Asian regions or races" (ibid.: 474).

Manu Goswami has interpreted the aesthetic radicalism and futurism of Sarkar and his support for cubism and the "pariahs of mankind" as one of the many forms of internationalism that flourished in the interwar period (Goswami 2012: 1483). His "futurist internationalism" of the 1920s was probably less robust in the 1930s but he looked forward to a more interdependent world economy. Sarkar disagreed with F. A. Hayek's critique of Soviet communist planning (Sarkar 1942a: 81) because he admired some of its achievements. He believed that the world had entered the phase of 'neo-capitalism' which was "capitalistic socialism or socialised capitalism" (Sarkar 1942a: 114) ${ }^{34}$ Public finance policies were buttressing, depending on ideologies, neo-capitalism and neo-despotocracy as well as neo-socialism and new democracy

${ }_{33}$ Sarkar also believed that the Asian struggle against albinocracy would proceed pari passu with the "struggle of the poor and pariah of the two hemispheres" against aristocracies based on wealth and birth (ibid.: 483).

${ }_{34}$ The growth of health and unemployment legislation in the west was evidence of 'solidarisme or class harmony' — of neo-capitalism or neo-socialism (ibid.: 43). Sarkar believed that nationalization of industries was primarily "a rationalization of capitalism" (Sarkar 1949: 74). 
(ibid.: 162). ${ }^{35}$ Sen's incisive discussion of the "romance of the state" (S. Sen 2015: 132-181), does not deal sufficiently with Sarkar's economic ideas and the role of the state in development. ${ }^{36}$

Sarkar believed that the interests of labour, the poor, the depressed classes could be promoted by appropriate planning and legislation. Writes Sarkar: "It is law that abolished serfdom as well as the guilds in Europe. It is likewise law that often made and unmade castes in ancient and medieval India and has been partially making and unmaking them in modern times too" (Sarkar 1941: 171). ${ }^{37}$ His ideas of authoritarian development included policies to promote welfare, social insurance, public health and housing. In 1942 Sarkar argued that in both Britain and Germany socialism in housing, health and sanitation had achieved great success from the late $19^{\text {th }}$ century onwards. Similar progress in rural reconstruction and education was also21 possible in India - despite poverty - based on "a more substantial patriotism, nationalistic or socialistic" (Sarkar 1942d: 200). In Villages and Towns in 1941 Sarkar claimed he was among the first to publish a Bengali study of socialism and labour in 1914-1915 and had translated a few Marxist texts during 1923-1925 (Sarkar 1941: 643). He declared, "It is on the principles of socialistic class-struggle that a new atmosphere can be generated among the Indian people" (ibid.: 644).

In Sarkar's assessment in 1941 neither the followers of Gandhi nor Bose could go far enough in addressing the problem of the poor or the pariah. The demands of the depressed classes and poor Muslims could not be met by the Congress, the Muslim League or the Hindu Mahasabha. He advocated socialism on nationalist foundations (Sarkar 1941: 645). Earlier in 1937 he had praised the shuddhi movement

$35 \quad$ Also see Sarkar 1937b: 349.

${ }^{36}$ Sarkar stated, "The economy that has been established in Soviet Russia is one of the greatest embodiments of satya (truth), shiva (good) and sundara (beauty) conceivable in human affairs" (Sarkar 1941: 579). In the same text critiquing the role of the Communist Party he argued that "the foundations of the satya, shiva and sundara that this regime represents are, therefore, anything but secure" (ibid.: 608-609).

For the role of power relations in shaping caste see Guha 2013. 
of Dayanand for uplifting the Harijans or the untouchables because it was different from the conservative ideas of Gandhi and the "some-what recalcitrant propaganda of Ambedkar, the apostle of the "untouchables"" (Sarkar 1937a: 464). ${ }^{38}$ He had not foregrounded the role of Phule and Ambedkar in his surveys of history but was definitely opposed to racism and caste discrimination. Therefore, some of Sarkar's ideas can also be placed in a democratic socialist or welfare capitalist repertoire.

Sarkar's understanding of history and contemporary society can neither be regarded as a derivative discourse nor a straightforward recovery or refurbishing of tradition. His specific arguments and efforts at creating a new vocabulary are important in reconstructing Indian intellectual engagement with national and international issues in the first half of the twentieth century. Sarkar's project of writing a history without Eurocentric biases and his hopes for mankind must not be eclipsed by the digressions and deviations in his long intellectual journey.

\section{References}

\section{Primary sources}

Sarkar, B. 1912. The Science of History and the Hope of Mankind. London and Calcutta: Longmans, Green, and Co.

Sarkar, B. 1914a. The Positive Background of Hindu Sociology, Book I. NonPolitical. Allahabad: Panini Office.

Sarkar, B. 1914b. The Sukraniti. Allahabad: Indian Press.

Sarkar, B. 1916a. Love in Hindu Literature. Tokyo: Maruzen Company.

Sarkar, B. 1916b. Chinese Religion Through Hindu Eyes: A Study in the Tendencies of Asiatic Mentality. Shanghai: The Commercial Press.

${ }_{38}$ Sarkar mentions the 'radical' Satyashodhak Samaj set up in 1873 but considers it less influential than the Arya Samaj set up in 1875 (ibid.: 520). 
Sarkar, B. 1917a. The Folk-Element in Hindu Culture. London: Longmans, Green and Co. Reprinted: 1972. New Delhi: Oriental Books.

Sarkar, B. 1917b. Varnasram-Dharma and Race-Fusion in India. In: The Modern Review, February: 211-215.

Sarkar, B. 1918a. The Futurism of Young Asia. In: International Journal of Ethics, 28(4): 521-541.

Sarkar, B. 1918b. Hindu Political Philosophy. In: The Political Science Quarterly, 33(4): 482-500.

Sarkar, B. 1918c. Hindu Achievements in Exact Science, New York and London: Longmans, Green and Co.

Sarkar, B. 1918d. Democratic Ideals and Republican Institutions in India. In: The American Political Science Review, 12(4): 581-606.

Sarkar, B. 1919a. The Democratic Background of Chinese Culture. In: The Scientific Monthly, 8(1): 58-65.

Sarkar, B. 1919b. An English History of India. In: The Political Science Quarterly, 34(4): 644-653.

Sarkar, B. 1922. The Futurism of Young Asia and Other Essays on the Relations Between the East and the West. Berlin: J. Springer.

Sarkar, B. 1926. Economic Development: Snapshots of World-Movements in Commerce, Economic Legislation, Industrialism and Technical Education. Madras: B. G. Paul \& Company.

Sarkar, B. 1928. The Political Philosophies Since 1905. Madras: B. G. Paul \& Company.

Sarkar, B. 1932. Studies in Applied Economics, Vol. I. Calcutta: Chuckervertty Chatterjee \& Co.

Sarkar, B. 1935. The Ain-i-Akbari As a Semi-Moslem And Semi-Hindu Arthasastra. In: The Calcutta Review, September: 245-256.

Sarkar, B. 1937a. Creative India: From Mohenjo Daro to the Age of RamakrishnaVivekananda. Lahore: Motilal Banarsi Dass.

Sarkar, B. 1937b. The Positive Background of Hindu Sociology, Book I. Introduction to Hindu Positivism. Allahabad: Panini Office.

Sarkar, B. 1937c. Social Metabolism in Its Bearings on Progress. In: Social Forces, 16(2): 169-177. 
Sarkar, B. 1938a [1927]. Greetings to Young India: Messages of Cultural and Social Reconstruction, Part I. Calcutta: N. M. Ray Chowdhury \& Co.

Sarkar, B. 1938b [1926]. The Politics of Boundaries. Calcutta: N. M. Ray Chowdhury.

Sarkar, B. 1939. The Sociology of Races, Cultures and Human Progress. Calcutta: Chuckervertty Chatterjee \& Co.

Sarkar, B. 1941. Villages and Towns as Social Patterns: A Study in the Processes and Forms of Societal Transformation and Progress. Calcutta: Chuckervertty Chatterjee \& Co.

Sarkar, B. 1942a. The Political Philosophies Since 1905, Vol. II. The Epoch of Neo-Democracy and Neo-Socialism (1929-), Part II. Lahore: Motilal Banarsi Dass.

Sarkar, B. 1942b. Miscellany. In: The Calcutta Review, March: 259-268.

Sarkar, B. 1942c. Miscellany. In: The Calcutta Review, April: 96-104.

Sarkar, B. 1942d. Miscellany. In: The Calcutta Review, May: 196-202.

Sarkar, B. 1943a. The Equations of World Economy in Their Bearings on PostWar Reconstruction. Calcutta: Chuckervertty Chatterjee \& Company.

Sarkar, B. 1943b. World-Politics and Post-War Economic Planning. In: The Indian Journal of Political Science, 5(2): 161-190.

Sarkar, B. 1949. Dominion India in World-Perspectives Economic and Political. Calcutta: Chuckervertty Chatterjee \& Co.

\section{Secondary sources}

Alam, M. 2004. The Languages of Political Islam in India, 1200-1800. Delhi: Permanent Black.

Alavi, S. 2015. Muslim Cosmopolitanism in the Age of Empire. Cambridge MA: Harvard University Press.

Anderson, B. 1983. Imagined Communities: Reflections on the Origin and Spread of Nationalism. London: Verso.

Basha, K. 1998. Indian Writings on Early History and Archaeology of Southeast Asia: A Historiographical Analysis. In: Journal of the Royal Asiatic Society, 8 (3): 395-410. 
Bhargava, R. 2016. An Ancient Indian Secular Age? In: A. Bilgrami (ed.). Beyond the Secular West. New York: Columbia University Press: 188-214.

Chakrabarty, D. 2000. Provincializing Europe: Postcolonial Thought and Historical Difference. Princeton: Princeton University Press.

Chung, T. 2009/2010. Towards a Grand Harmony. In: India International Centre Quarterly, 36(3/4): 2-19.

Datla, K. 2009. A Worldly Vernacular: Urdu at Osmania University. In: Modern Asian Studies, 43(5): 1117-1148.

Devji, F. 2015. Catching up with Oneself: Islam and the Representation of Humanity. In: H. Truper et al. (eds.). Historical Teleologies in the Modern World, London: Bloomsbury: 301-320.

Dhammadipa, B. 2015. Kumārajīva's Meditative Legacy in China. In: Spirituality Studies, 1(2): 1-10.

Framke, M. 2013. Fascist Italy: Ideal Template for India's Economic Development? In: H. Schulz-Forberg (ed.). Zero Hours: Conceptual Insecurities and New Beginnings in the Interwar Period. Brussels: Peter Lang: 77-96.

Ghoshal, U. N. 1927. More Light on Methods and Conclusions in Hindu Politics. In: Indian Historical Quarterly, 3(3/4): 625-658.

Gopal, L. 1962. The "Śukranīti"-A Nineteenth-Century Text. In: Bulletin of the School of Oriental and African Studies, 25(1/3): 524-556.

Goswami, M. 2012. Imaginary Futures and Colonial Internationalisms. In: The American Historical Review, 117(5): 1461-1485.

Goswami, M. 2013. "Provincializing" Sociology: The Case of a Premature Postcolonial Sociologist. In: Postcolonial Sociology. Political Power and Social Theory, 24: 145-175.

Guha, S. 2013. Beyond Caste: Identity and Power in South Asia, Past and present. Leiden: Brill.

Hobsbawm, E. 1994. The Age of Extremes: The Short Twentieth Century, 1914-1991. New York: Vintage.

Jalal, A. 2000. Self and Sovereignty: Individual and Community in South Asian Islam Since 1850. London: Routledge.

Kapila, S. and Devji, F. (eds.). 2013. Political Thought in Action: The Bhagavad Gita and Modern India. Cambridge: Cambridge University Press. 
Kaviraj, S. 2016. Disenchantment Deferred. In: A. Bilgrami (ed.). Beyond the Secular West. New York: Columbia University Press: 135-187.

Kolff, D. 2002. Naukar, Rajput, and Sepoy: The Ethnohistory of the Military Labour Market of Hindustan, 1450-1850. Cambridge: Cambridge University Press.

Kulke, H, 1993a. Max Weber's Contribution to the Study of "Hinduization" in India and "Indianization" in Southeast Asia. In: Kings and Cults: State Formation and Legitimation in India and Southeast Asia. Delhi: Manohar.

Kulke, H, 1993b. The Devaraja Cult: Legitimation and Apotheosis of the Ruler in the Kingdom of Angkor. In: Kings and Cults: State Formation and Legitimation in India and Southeast Asia. Delhi: Manohar.

Kulke, H. 2016. Śrīvijaya Revisited: Reflections on State Formation of a Southeast Asian Thalassocracy. In: Bulletin de l'École française d'ExtrêmeOrient, 102: 45-96.

Manjapra, K. 2014. Age of Entanglement: German and Indian Intellectuals Across Empire. Cambridge MA: Harvard University Press.

Mukherjee, H. 1950. Benoy Sarkar As A Pioneer of Neo-Indology. In: The Modern Review, 87: February: 134-138.

Muyou, F. 2016. A Re-examination of the Influence of Kumārajīva's Thought on His Translation of the Vimalakīrtinirdeśa. In: The Eastern Buddhist, 47(1): 57-80.

Namakkal, J. 2019. Decolonizing Marriage and the Family: The Lives and Letters of Ida, Benoy, and Indira Sarkar. In: Journal of Women's History, 31(2): Summer: 124-147.

Parthasarathi, P. 2011. Why Europe Grew Rich and Asia Did Not: Global Economic Divergence, 1600-1850. Cambridge MA: Cambridge University Press.

Pomeranz, K. 2000. The Great Divergence: China, Europe, and the Making of the Modern World Economy. Princeton University Press.

Rudolph, L. and S. Rudolph. 2006. Postmodern Gandhi and Other Essays. Chicago University Press.

Sen, S. 2013. Benoy Kumar Sarkar and Japan. In: Economic and Political Weekly, 48 (45/46): 16 November: 61-70.

Sen, S. 2015. Benoy Kumar Sarkar: Restoring the Nation to the World. New Delhi: Routledge. 
Sen, S. 2017. The Conservative Animal: Bhudeb Mukhopadhyay and Colonial Bengal. In: The Journal of Asian Studies, 76(2): May: 363-381.

Sen, T. 2001. In Search of Longevity and Good Karma: Chinese Diplomatic Missions to Middle India in the Seventh Century. In: Journal of World History, 12(1): 1-28.

Sen, T. 2010a. Changes and Exchanges. In: India International Centre Quarterly, 36(3/4): 34-47.

Sen, T. 2010b. The Intricacies of Premodern Asian Connections. In: The Journal of Asian Studies, 69(4): November: 991-999.

Six, C. 2018. Challenging the grammar of difference: Benoy Kumar Sarkar, global mobility and anti-imperialism around the First World War. In: European Review of History, 25, 3-4, 431-449.

Smith, A. 1986. The Ethnic Origins of Nations. Oxford: Blackwell.

Stewart, T. 2000. Alternate Structures of Authority Satya Pir on the Frontiers of Bengal. In: D. Gilmartin and B. B. Lawrence (eds.). Beyond Turk and Hindu: Rethinking Religious Identities in Islamicate South Asia. University of Florida Press: 21-54.

Stewart, T. 2001. In Search of Equivalence: Conceiving Muslim-Hindu Encounter through Translation Theory. In: History of Religions, 40(3): February: 260-287.

Stolte, C. and H. Fischer-Tiné. 2012. Imagining Asia in India: Nationalism and Internationalism (ca. 1905-1940). In: Comparative Studies in Society and History, 54(1): January: 65-92.

Stolte, C. 2016. Compass Points: Four Indian Cartographies of Asia, ca. 1930-1955. In: M. Frey and N. Spakowski (eds.). Asianisms: Regionalist Interactions and Asian Integration. Singapore: National University of Singapore Press: 49-74.

Veer van der, P. 2001. Imperial Encounters: Religion and Modernity in India and Britain. New Jersey: Princeton.

Zachariah, B. 2001. Uses of Scientific Argument: The Case of 'Development' in India, c. 1930-1950. In: Economic and Political Weekly, 36 (39): 29 September-5 October: 3689-3702. 
Zachariah, B, 2010. Rethinking (the Absence of) Fascism in India. In: S. Bose and K. Manjapra (eds.). Cosmopolitan Thought Zones: South Asia and the Global Circulation of Ideas. New York: Palgrave Macmillan: 178-209.

Zachariah, B. 2014. A Voluntary Gleichschaltung? Perspectives from India Towards a Non-Eurocentric Understanding of Fascism. In: Transcultural Studies, 2: December: 8-44.

Zachariah, B. 2015a. Global Fascisms and the Volk: The Framing of Narratives and the Crossing of Lines. In: South Asia: Journal of South Asian Studies, 38(4): 608-612.

Zachariah, B. 2015b. At the Fuzzy Edges of Fascism: Framing the Volk in India. In: South Asia: Journal of South Asian Studies, 38(4): 639-655. 